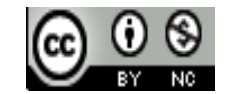

Jurnal Pendidikan Matematika Indonesia is licensed under A Creative Commons Attribution-Non Commercial 4.0 International License.

\title{
PENGARUH EMOTIONAL INTELLIGENCE TERHADAP HASIL BELAJAR SISWA MTS. MUHAMMADIYAH 1 KOTA SORONG
}

\author{
Zakiyah Anwar ${ }^{1)}$, Faisal Eka Mahendra ${ }^{2)}$, Arie Anang Setyo ${ }^{3)}$, Irna Rusani ${ }^{4)}$, Supriadi ${ }^{5)}$ \\ 1) Universitas Muhammadiyah Sorong,Kota Sorong, Indonesia \\ E-mail: zakiyahanwar@um-sorong.ac.id \\ 2) Universitas Muhammadiyah Sorong,Kota Sorong, Indonesia \\ E-mail: faisalekamahendra132@gmail.com \\ 3) Universitas Muhammadiyah Sorong,Kota Sorong, Indonesia \\ E-mail: arieanangsetyo.ums@gmail.com : \\ 4) Universitas Muhammadiyah Sorong,Kota Sorong, Indonesia \\ E-mail: irnarusani.ums@gmail.com \\ 5) Universitas Muhammadiyah Sorong,Kota Sorong, Indonesia \\ E-mail: supriadi.ums@gmail.com
}

\begin{abstract}
Abstrak. Tujuan Penelitian ini untuk melihat seberapa besar pengaruh Kecerdasan Emosional terhadap hasil belajar siswa MTs. Muhammadiyah I Kota Sorong. Jenis penelitian ini adalah penelitian eksperimen dan Subjek pada penelitian ini berjumlah 30 siswa. Setelah data dianalisis dan diperoleh hasil perhitungan Uji t diperoleh nilai thitung yaitu -24,650 lebih kecil dari $t_{\text {tabel }}$ yaitu 2,048, yang berarti ada pengaruh Kecerdasan Emosional terhadap hasil belajar siswa MTs. Muhammadiyah 1 Kota Sorong. Sedangkan data hasil rata - rata pretest sebelum diberi perlakuan 18,88 , Sementara untuk nilai posttest setelah diberi perlakuan diperoleh 74,80 ini menunjukkan bahwa nilai rata - rata diatas KKM 67. Lembar observasi pengamatan aktivitas peserta didik siswa diketahui berada pada kategori baik, hal ini membuktikan mereka mendengarkan dengan seksama semua yang disampaian oleh guru. Dan untuk angket respon siswa pada setiap indikator yang direspon berdasarkan hasil yang diperoleh semua berada pada kategori positif.
\end{abstract}

Kata Kunci: Kecerdasan Emosional, hasil belajar, aktivitas siswa, respon siswa

\section{PENDAHULUAN}

Penilaian yang digunakan oleh guru di Indonesia dalam menilai prestasi atau hasil belajar siswa pada umumnya hanya menggunakan tes untuk mengukur aspek kognitif atau penguasaan pengetahuan peserta didik saja, padahal dalam kependidikan kemampuan peserta didik meliputi tiga aspek yaitu aspek psikomotorik, aspek kognitif dan afektif. Selain itu, tes yang digunakanpun pada umumnya hanya dapat mengukur kemampuan berpikir dalam tingkat kognitif yang rendah. Gambaran penilaian prestasi belajar siswa yang hanya berfokus pada nilai kognitif atau kecerdasan intelektual (Intelligence Quotient) juga menjadi tolak ukur akan rendahnya metode penilaian yang dilakukan oleh guru pada umumnya. Berbagai penelitian menunjukkan bahwa kesuksesan dalam prestasi atau hasil belajar siswa tidak hanya di tentukan oleh kecerdasan intelektual (IQ). Kecerdasan emosional (Emotional Intelligence) juga merupakan salah satu faktor penting dalam menilai prestasi atau hasil belajar siswa (Naqvi, 2016:210).

Para ahli psikolog seperti Daniel Goleman sepakat bahwa IQ hanya mendukung $20 \%$ faktor yang menentukan keberhasilan, sedangkan $80 \%$ sisanya berasal dari faktor lain, termasuk kecerdasan emosional (Emotional Intelligence) (Goleman, 2016:42). Kenyataannya, dalam proses pembelajaran di sekolah sering ditemukan siswa yang tidak dapat meraih prestasi atau hasil belajar yang setara dengan kemampuan inteligensinya. Dalam proses belajar siswa, intelegensi dan emosional sangat berpengaruh dan sangat diperlukan. IQ seseorang tidak akan berfungsi dengan normal tanpa adanya stimulus berupa partisipasi penghayatan emosional pada proses pembelajaran yang 


\section{- - - Jurnal Pendidikan Matematika Indonesia \\ Volum 5 Nomor 1 bulan Maret 2020. Page 24 - 30 \\ p-ISSN: 2477-5967 e-ISSN: 2477-8443}

disampaikan di kelas. Namun biasanya IQ dan EQ merupakan kunci keberhasilan belajar siswa di sekolah (Goleman, 2009, dalam Firmansyah, 2010:4). Pendidikan di sekolah penting untuk mengembangan rasional intelligence yaitu model memahaman lazimnya dipahami siswa saja, melainkan juga perlu mengembangkan emotional intelligence siswa. perlu diakui bahwa mereka yang memiliki IQ sedang akan sedikit mengalami kesulitan dalam mengikuti pendidikan yang diberikan oleh pengajar. Namun dapat dilihat bahwa tidak sedikit orang yang memiliki IQ tinggi memiliki prestasi rendah, ada beberapa orang dengan kemapuan IQ sedang yang dapat mengungguli prestasi belajar sesorang dengan IQ tinggi. Hal ini jelas menunjukkan bahwa sesorang dengan IQ baik itu sedang atau tinggi tidak selalu dapat memperkirakan prestasi belajar seseorang (Firmansyah, 2010:4).

Dalam Seri Analisis Pembangunan Wilayah Papua Barat tahun 2015 menyatakan bahwa secara umum tingkat pendidikan di Papua Barat lebih baik apabila dibandingkan Provinsi Papua, namun masih jauh dibandingkan provinsi lain di Indonesia. Hal ini disebabkan oleh salah satu faktor yang paling dominan yaitu kurangnya jumlah tenaga pengajar serta masih rendahnya kualitas tenaga pengajar yang ada di Papua Barat, sehingga dapat mempengaruhi prestasi atau hasil belajar siswa di daerah Papua Barat (Badan Pusat Statistik Provinsi Papua Barat, 2016).

Berdasarkan paparan di atas dapat dinilai adanya keterkaitan yang erat antara kecerdasan emosional (EQ) dengan pembelajaran yang melibatkan aspek kognitif, afektif, dan psikomotorik terhadap keberhasilan proses pembelajaran matematika. Aspek-aspek tersebut dapat diaplikasikan oleh guru dalam membimbing siswa untuk menyelesaikan problem matematika. Penelitian ini bertujuan untuk mengetahui Seberapa besar pengaruh emotional intelligence terhadap hasil belajar siswa di MTs. Muhammadiyah I Kota Sorong dan Seberapa besar peningkatan hasil belajar siswa dengan adanya emotional intelligence . tentunya hasil penelitian ini akan menjadi bahan masukan dalam melaksanakan proses pembelajaran matematika bagi siswa nya di MTs. Muhammadiyah I serta dapat menjadi terobosan untuk meningkatkan sistem penilaian terhadap hasil belajar siswa.

Emotional Intelligence sangat di perlukan seseorang sebagai kemampuan dalam memotivasi diri sendiri dn dalam menghadapi frustasi dalam kehidupan dalam hal dorongan hati yang tidak puas dengan keadaan, dan tentunya menjaga agar suasana hati tetap stabil, berempati dan berdoa. Berbeda dengan IQ, Senada dengan pemikiran diatas bahwa kecerdasan emosi sebagai suatu kemampuan untuk mengenali perasaan diri maupun perasaan orang lain, kemampuan memotivasi diri sendiri, kemampuan mengolah emosi dalam diri sendiri dan membina hubungan dengan orang lain meliputi kemampuan mengatasi frustasi, mengendalikan dorongan dalam hati dan menjaga beban stres supaya tidak melumpuhkan kemampuan berfikir serta bersimpati. Kecerdasan emosional sangat dipengaruhi oleh lingkungan, bersifat tidak menetap dan berubah-ubah setiap saat. Oleh karena itu, lingkungan sangat berperan dalam pembentukan kecerdasan emosional individu terutama lingkungan keluarga. kecerdasan emosional pada penelitian ini merupakan kemampuan individu untuk dapat mengenali emosi diri, mengelola emosi diri, memotivasi diri sendiri, dan dapat mengenali emosi orang (empati) dan tentunya dapat membina hubungan dengan orang lain.

Kecerdasan emosional terbagi dalam beberapa komponen yang membentuknya.(Goleman,2016:56) mengklasifikasikan kecerdasan emosional dalam lima kemampuan utama, yaitu: (1) Mengenali emosi diri artinya Kemampuan mengenali diri sendiri merupakan kemampuan dasar dari kecerdasan emosional. Inti dari mengenali emosi diri adalah kesadaran diri. Kemampuan ini memiliki peranan untuk memantau perasaan dari waktu ke waktu. Selain itu, juga berfungsi untuk mencermati perasaan- perasaan yang muncul pada suatu saat. (2) Mengelola emosi diri yaitu kemampuan diri dalam mengelola perasaan dan emosi. Hal ini harus di barengi dengan kesadaran diri yang meliputi kesadaran akan diri sendiri dan kemapuan dalam membahagiakan diri sendiri termasuk dapat mengelola kecemasan dan ketersinggungan dan hal hal yang timbul dari ketidaksadaran diri mengelola keterampilan dasar emosi. Individu yang terampil dalam mengelola emosi dari dalam diri akan mampu menenangkan diri dari kekacauan-kekacauan yang sedang di alami sehingga dapat bangkit kembali. Sebaliknya, individu yang memiliki kemampuan buruk dalam mengelola emosi akan akan mudah dirundung perasaan murung. (3) Memotivasi diri sendiri yaitu keterampilan dasar diri memotivasi yang meliputi pengendalian akan dorongan yang terdapat dalam hati, kemampuan berfikir positif, dan optimisme. Individu yang memiliki keterampilan memotivasi diri sendiri dengan baik cenderung jauh lebih baik produktif serta efektif dalam segala tindakan yang dikerjakannya. Kemampuan berasal dari kemampuan dalam mengelola emosi, yaitu menahan diri sendiri dari kepuasan akan dorongan untuk bisa unggul atau dapat memenuhi standar keberhasilan) dan mengendalikan dorongan hati. (4) dapat Mengenali perasaan/emosi orang lain dalam hal ini berempati, dimana Empati merupakan suatu keterampilan dasar dalam bergaul yang juga bergantung pada kemampuan dari kesadaran diri emosional. Kemampuan berempati meliputi kemampuan untuk mengetahui bagaimana perasaan seseorang, dapat memahami cara pandang seseorang, menumbuhkan perasaan saling percaya serta menyelaraskan diri dengan orang lain. Individu yang empati mampu melihat kondisi sosial yang terdapat pada seseorang yang mengisyratkan apa dikehendaki oleh orang lain. (5) Membina suatu hubungan pada orang lain yaitu Keterampilan membina hubungan merupakan keterampilan yang dapat mendongkrak prestasi, kepemimpinan, dan keberhasilan hubungan antarpribadi. Seseorang yang memiliki keterampilan dalam membangun hubungan dengan orang lain dengan baik dapat menjaga hubungan dengan baik dan lancar serta mampu peka terhadap lingkungan dan emosi orang lain, dalam hal ini seseorang mampu memimpin dan mengorganisisr organisasi serta pandai memberikan solusi dalam setiap permasalahan. 


\section{- - - - Jurnal Pendidikan Matematika Indonesia \\ Volum 5 Nomor 1 bulan Maret 2020. Page 24 - 30 \\ p-ISSN: 2477-5967 e-ISSN: 2477-8443}

Faktor- Faktor yang Mempengaruhi Kecerdasan Emosional menurut Goleman (Kumala, 2015:32) menjelaskan bahwa ada dua faktor yang mempengaruhi kecerdasan emosional seseorang, yaitu: Lingkungan Keluarga dan Lingkungan Non Keluarga. Lingkungan dalam keluarga merupakan hal pertama yang menjadi sekolah yang menjadi tempat mengolah perasaan dan emosi yang di pelajari dari orang tua mereka. Ini karena orang Tua merupakan orang pertama yang perilakunya akan di tiru, diinternalisasi yang kemuadian akan menjadi jatidiri atau kepribadian seorang anak. Kecerdasan emosi seoarang anak dapat diajarkan pada anak yang masih bayi dengan memberikan contoh-contoh ekspresi secara langsung, sebagai contoh: anak di latih pada kebiasaan disiplin dan bertanggung jawab, kemampuan dalam berempati dengan seseoarng, kepedulian yang baik. Kecerdasan emosional seseorang dapat dengan baik berkembang sesuai dengan kondisi seseorang sesuai pada umurnya. Pembelajaran ini ditunjukkan dalam kegiatan sehari hari seperti bermain boneka, bermain tukar peran. Anak yang bermain dengan berperan sebagai seseorang/individu, dengan melibatkan emosi pada peran yang dimainkan pada saat bermain anak akan mulai memahami perasaan orang lain, hal ini dapat mengembangan kecerdasan emosional anak, masih banyak permainan yang dapat mengolah perasaan yang dapat mengolah rasa empati pada diri seorang anak. Penilaian pada hal sikap merupakan perilaku yang mengarah pada kecenderungan berinteraksi sosial dalam kehidupan sehari hari baik itu dalam kelas maupun di keluar kelas sebagai bagian dari pendidikan. Penilaian sikap ini dalam rangka untuk mengetahui perkembangan dari sikap anak dengan melihat perilaku sikap sesuai dengan KD dari KI-1 dan KI-2 (Kemendikbud, 2015).

Pada kurikulum 2013 menuntut pembentukkan sikap melalui kegiatan belajar mengajar wajib dilakukan, sehingga standar penilaian mencakup sikap merupakan suatu kewajiban yang harus dilakukan dan dilaporkan. Pengukuran sikap yang harus dilakukan oleh guru menurut Permendikbud Nomor 66 Tahun 2013 antara lain: penilaian diri, observasi perilaku, penilaian teman sejawat, dan laporan pribadi (jurnal). Metode penilaian tersebut dijabarkan sebagai berikut:

Observasi Perilaku

Perilaku seseorang pada umumnya menunjukkan kecendrungan seseorang dalam suatu hal. Misalnya orang yang biasa membaca buku, dapat dipahami sebagai kecendrungannya yang senang membaca buku. Oleh sebab itu, seorang guru dapat melakukan kegiatan observasi perilaku peserta didik yang mengikuti proses belajar mengajar. Hasil dari observasi dijadikan sebagai umpan balik pada pembelajaran.

Dalam hal Penilaian Teman sejawat, Salah satu metode penilaian sikap yang perlu dilakukan dan dapat membantu guru melakukan penilaian secara lebih komprehensif adalah penilaian oleh teman sejawat. Keterbatasan guru dalam mengobservasi menjadi sulit dilakukan. Rubrik penilaian sikap dengan indikator atau kriteria yang sama diisi oleh guru dan teman sejawat. Jika dijadikan sebagai lembar penilaian oleh teman sejawat dalam satu kelompok, maka nama teman yang dinilai harus dicantumkan. Jurnal Jurnal merupakan catatan guru, didalam catatan tersebut berisi informasi dari pengamatan proses pembelajaran dan berisi hal hal yang menjadi koreksi baik itu kelemahan dan kekuatan dari sikap atau perilaku peserta didik di dalam dan di luar kelas. Jurnal merupakan catatan yang berkesinambungan berdasarkan hasil observasi oleh guru dalam rentang waktu tertentu. Guru perlu mempersiapkan lembaran pengamatan untuk mengamati sikap dan perilaku peserta didik pada waktu yang ditentukan. Jurnal juga dapat diisi oleh masing- masing peserta didik, dan hasilnya direkapitulasi oleh guru.

Hipotesis Penelitian ini Berdasarkan kajian teori dan kerangka berfikir dapat diajukan hipotesis sebagai jawaban sementara terhadap permasalahan yang dihadapi, yaitu "Terdapat pengaruh antara Emotional Intelligence dengan penilaian hasil belajar Siswa Kelas VIII di MTS Muhammadiyah I Kota Sorong”.

\section{METODE PENELITIAN}

Jenis penelitian ini menggunakan pendekatan Quasi Eksperiment dengan Desain penelitian yang digunakan adalah The Equivalent Material Group, pre test - post test design atau One Group Pre Test - Post Test Design. pertama- tama dilakukan tes awal pembelajaran suatu materi, setelah itu diberikan perlakuan dengan menerapkan metode pembelajaran yang mengaplikasikan kecerdasan emosional (emotional intelligence). Setelah itu, kemudian dilakukan observasi dengan digunakan instrumen yang sama dengan yang dilakukan sebelum perlakuan (Zarkasyi, 2015:122).

$$
\text { E O X O }
$$

Keterangan:

E : Kelas Eksperimen

O : Pre-Test/ Post Test (variabel dependen yang diobservasi)

X : Perlakuan yang diberikan (Variabel Independen)

Populasi penelitian adalah siswa Kelas VIII MTs. Muhammadiyah 1 Kota Sorong dengan sampel dalam penelitian ini adalah siswa Kelas VIIIB MTs. Muhammadiyah 1 Kota Sorong dengan jumlah 30 siswa.

Variabel penelitian ini terdiri dari 2 yaitu yaitu: Variabel independen adalah Emotional Intelligencence (kecerdasan emosional) dan Variabel dependen Variabel yaitu penilaian hasil belajar siswa. Penilaian hasil belajar merupakan proses pemberian nilai terhadap hasil- hasil belajar yang dicapai siswa dengan kriteria tertentu.

Teknik dari pengumpulan data pada penelitian ini adalah teknik tes dan non tes yaitu Observasi, Angket serta Tes. Teknik pengumpulan data yang digunakan dalam penelitian ini adalah Observasi partisipatif. Dalam observasi ini peneliti terlibat dengan kegiatan sehari-hari siswa. Angket/ Kuesioner adalah sebuah teknik pengumpulan data dengan cara memberikan seperangkat pertanyaan atau pernyataan yang tertulis kepada responden (Sugiyono, 2015:199). Jenis 
angket atau kuesioner yang digunakan pada penelitian ini adalah menggunakan angket atau kuesioner tertutup karena siswa hanya memilih jawaban yang telah disediakan. Tes yang diberikan dalam penelitian ini berupa pre-test dan posttest. Pre-test merupakan tes yang diberikan bertujuan untuk mengetahui kemampuan awal siswa dalam pembelajaran matematika sebelum mendapat perlakuan. Sedangkan posttest merupakan tes yang diberikan setelah siswa mendapatkan perlakuan. Penelitian ini menggunakan instrumen pengumpulan data berupa lembar observasi, angket respon dan tes.

Dalam Uji Validitas Instrumen, Suatu data dikatakan valid jika sesuai dengan keadaan sebenarnya. Instrumen pada penelitian ini terbagi menjadi dua yaitu, intrumen non tes dan tes untuk validitas instrument non tes peneliti menggunakan tim ahli sebagai validator yaitu tim ahli akan diberikan lembar observasi, dan angket respon yang sudah disusun oleh peneliti, kemudian tim ahli akan memberikan penilaian kesesuaian instrumen yang dibuat menurut aspek isi, bahasa, dan penyajian. Sedangkan untuk validitas tes peneliti mengunakan korelasi product moment dan bantuan program SPSS 24.0

Analisis statistik deskriptif ini digunakan untuk menganalisis data hasil observasi, datahasil respon siswa dan hasil belajar siswa. Pengamatan aktivitas peserta didik dalam proses belajar mengajar melalui lembar observasi dianalisis dengan menggunakan persentase. Presentase pengamatan aktivitas siswa yaitu jumlah soal yang dijawab benar dibagi jumlah butir soal dikali 100\%.Indikator aktivitas siswa yang diamati dalam proses pembelajaran berlangsung yaitu, mengenali emosi diri, mengelola emosi diri, memotivasi diri sendiri, mengenali emosi orang lain (empati) dan membina hubungan dengan orang lain.

TABEL I

\section{KATEGORI ASPEK AKTIVITAS SISWA}

\begin{tabular}{cll}
\hline No. & Skor Rata-rata & \multicolumn{1}{c}{ Kategori } \\
\hline 1 & $1,0-1,4$ & $\begin{array}{l}\text { Sangat } \\
\text { Baik }\end{array}$ \\
2 & $1,5-2,4$ & Tidak \\
3 & $2,5-3,4$ & Tidak Baik \\
4 & $3,5-4,0$ & Sangat Baik \\
\hline & & (Setyo, 2016:73)
\end{tabular}

Data respon siswa akan diperoleh dari hasil angket yang diberikan kepada siswa setelah pembelajaran berakhir. Keefektifan dari respon siswa diukur dengan menggunakan kategori selalu, sering, kadang-kadang dan tidak pernah. Kriteria keefektifan tersebut ditentukan dengan menghitung masing-masing skor rata-ratnya. Adapun penentuan kategori aspek respon siswa ditentukan berdasarkan kriteria pada Tabel II
TABEL II

KATEGORI ASPEK RESPON SISWA

\begin{tabular}{rrl}
\hline No. & Skor Rata-rata & Kategori \\
\hline 1 & $1,0-1,4$ & Negatif \\
2 & $1,5-2,4$ & Cenderung Negatif \\
3 & $2,5-3,4$ & Cenderung Positif \\
4 & $3,5-4,0$ & Positif \\
\hline
\end{tabular}

(Setyo, 2016:76)

TABEL III

KATEGORI HASIL BELAJAR SISWA

\begin{tabular}{rcl}
\hline No. & Tingkat kemampuan siswa & \multicolumn{1}{c}{ Kategori } \\
\hline 1 & $86-100$ & Sangat Baik \\
2 & $71-85$ & Baik \\
3 & $56-70$ & Cukup \\
4 & $<55$ & Kurang \\
\hline
\end{tabular}

Uji Hipotesis dalam menganalisis data dalam penelitian ini, peneliti menggunakan uji-T atau T-Test. Dalam penelitian ini peneliti menggunakan teknik analisis Uji t- 2 Sampel Berpasagan (Paired Sampel). Uji hipotesis dengan menggunakan Uji t Paired Sampelyaitu pengujian untuk mengetahui apakah ada perbedaan nilai dari satu sampel sebelum dan sesudah dilakukan perlakuan tertentu. Pengujian ini bisa dilakukan dengan bantuan SPSS 24.0 For windows menggunakan $\alpha$ 0,05. Pengujian dua sampel, namun sebenarnya menggunakan sampel yang sama.

Dasar pengambilan keputusan berdasarkan probabilitas (sig.2-tailed) Jika probabilitas (sig.2-tailed) > 0,05 maka Ho diterima, Jika probabilitas (sig.2-tailed) $<0,05$ maka Ho ditolak

Uji Regresi Sederhana

Persamaan regresi dapat digunakan untuk melakukan prediksi seberapa tinggi nilai variabel dependen bila nilai variabel independen dimanipulasi (dirubah-rubah). Secara umum persamaan regresi sederhana (dengan satu prediktor dapat dirumuskan sebagai berikut :

$$
Y^{\prime}=a+b X
$$

(Sugiyono, 2012: 262)

\section{HASIL PENELITIAN DAN PEMBAHASAN}

Sebelum melakukan penelitian, peneliti terlebih dahulu melakukan validasi instrumen dan perangkat penelitian, validasi ini digunakan untuk mendapatkan instrumen penelitian dan perangkat yang berkriteria valid. Instrumen penelitian dan perangkat yang divalidasi diantaranya adalah Rencana Pelaksanaan Pembelajaran (RPP), Lembar Kegiatan Siswa (LKS), Lembar Observasi Aktivitas Siswa dan Angket Respon Siswa, kemudian di validasi dengan membuat 
lembar validasi dan dikonsultasikan ke pakar matematika (Validator) untuk mendapatkan saran dari pakar tersebut. hasil validasi Rencana Pelaksanaan Pembelajaran (RPP), Lembar Kegiatan Siswa (LKS), Lembar Observasi Aktivitas Siswa dan Angket Respon Siswa dalam penelitian ini antara lain dapat dilihat pada gambar 1 dibawah ini:

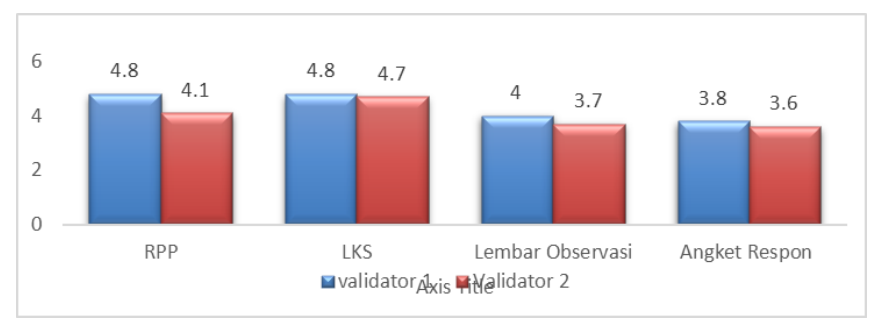

Gambar 1 Hasil Validasi Insrumen

Dari hasil perhitungan pada gambar 1,menujukkan hasil validasi dari validator 1 untuk validasi RPP rata-ratanya 4,8 dan validasi LKS 4,8 sedangkan dari validator 2 untuk validasi RPP 4,1 dan validasi LKS 4,7 dengan rata-rata skore maksimum perolehan 5sehingga RPP dan LKS dinyatakan dapat diterapkan dengan revisi kecil (Valid) sesuai saran yang diberikan kepada peneliti. Sehingga RPP dan LKS dapat dipakai untuk penelitian.Hasil validasi Lembar Observasi Aktivitas Siswa dan angket respon oleh validator 1 berturut-turut sebesar 4 dan 3,8 sedangkan oleh validator 2 sebesar 3,7 dan 3,6 dengan rata-rata skore maksimum sebesar 4. Sehingga lembar observasi dan angket respon dinyatakan dapat diterapkan dengan revisi kecil (Valid) sesuai saran yang diberikan kepada peneliti. Sehingga RPP dan LKS dapat dipakai untuk penelitian.

Uji validitas dilakukan dengan menggunakan software SPSS 24.0. Soal yang tidak valid akan dibuang dan tidak digunakan sedangkan item yang valid dapat digunakan untuk penelitian sebagai soal pretest dan posttest.

Tabel IV

HASIL UJI VALIDITAS

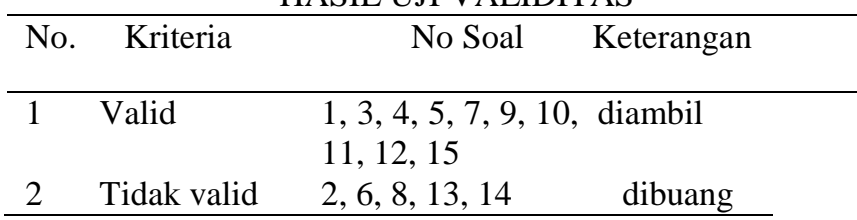

Dari hasil analisa menggunakan software SPSS 24.0 diperoleh 10 soal yang dinyatakan valid berdasarkan hasil rhitung $>0,444$ sehingga instrumen dapat digunakan. Uji reliabilitas dilakukan dengan teknik Croncbach's Alpha. Berdasarkan uji coba soal yang telah dilaksanakan dengan $\mathrm{N}$ $=20$ dan taraf signifikan 5\% diperoleh rtabel $=0,444$ berdasarkan $\mathrm{R}$ tabel. 10 soal dinyatakan reliabel. Terdapat 10 soal yang telah diujicobakan dan dinyatakan valid, dan soal terebut diujikan pada uji reliabilitas, ini dapat dilihat berdasarkan hasil software SPSS 24.0 yang nilai Croncbach's Alpha adalah 0,886 yang masuk pada kategori kriteria reliabel sangat tinggi dan nilai rtabel dari $\mathrm{N}=20$ dengan taraf signifikansi $5 \%$ didapat rtabel adalah 0,444.
Hasil yang didapat yaitu rhitung $>\operatorname{rtabel}(0,886>0,444)$ Sehingga dapat digunakan sebagai instrumen.

Adapun data hasil observasi aktivitas siswa untuk setiap pertemuan pada kelas yang di ajar dengan model pembelajaran kooperatif dan yang diamati oleh observer adalah emotional intelligence (kecerdasan emosional) siswa pada saat proses pembelajaran berlangsung. Data hasil observasi dapat di lihat pada tabel $\mathrm{V}$

TABEL V

RATA- RATA HASIL LEMBAR OBSERVASI AKTIVITAS SISWA

\begin{tabular}{lllll}
\hline No. & $\begin{array}{l}\text { Pengamatan } \\
\text { Aktivitas } \\
\text { Siswa }\end{array}$ & $\begin{array}{c}\text { Rata- } \\
\text { rata }\end{array}$ & $\begin{array}{l}\text { Kate } \\
\text { gori }\end{array}$ & $\begin{array}{l}\text { Persent } \\
\text { ase }\end{array}$ \\
\hline 1 & Pert 1 & 2,97 & Baik & $74,2 \%$ \\
2 & Pert 2 & 2,97 & Baik & $74 \%$ \\
3 & Pert 3 & 2,90 & Baik & $72,5 \%$ \\
4 & Pert 4 & 2,90 & Baik & $73 \%$ \\
\hline & Rata-rata & 3,10 & Baik & $73,5 \%$ \\
\hline
\end{tabular}

Berdasarkan tabel IV dapat dilihat bahwa nilai rata-rata lembar observasi aktivitas siswa pada setiap pertemuan berada pada kategori baik. Jika setiap pertemuan hasilnya di rata- rata menjadi 3,10 dengan hasil presentase $73,5 \%$. Jadi kelas tersebut berada pada kategori yang sangat baik.

Data respon siswa disusun berdasarkan indikator yang dapat mengungkapkan kecerdasan emosional siswadan tentunya berhubungan dengan proses pembelajaran yaitu respon terhadap model pembelajaran kooperatif. Respon siswa ini didapat dari setiap siswa yang merespon pernyataan pada lembar angket respon yang diberikan kepada setiap siswa. Data hasil angket respon dapat di lihat pada tabel VI

TABEL VI

HASIL ANGKET RESPON SISWA

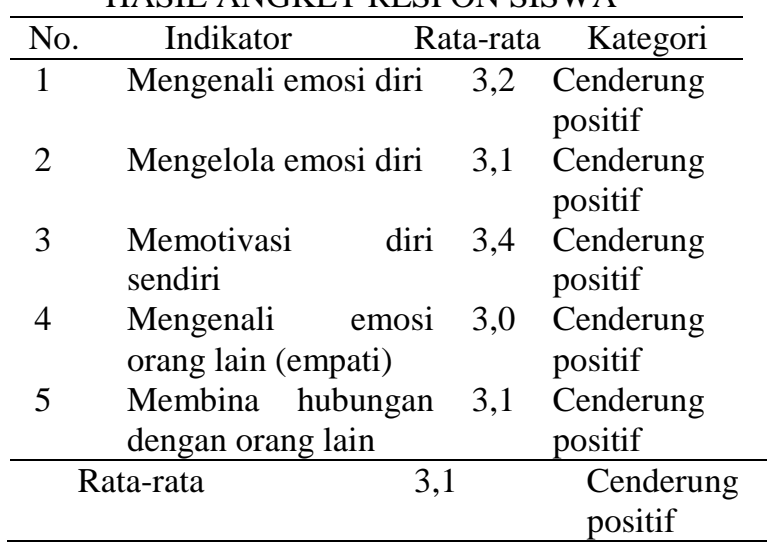

Berdasarkan tabel VI dapat dilihat bahwa nilai rata-rata angket respon siswa pada setiap indikator berada pada kategori cenderung positif. Jika setiap indikator di rata-rata menjadi 3,1 jadi kelas tersebut merupakan kategori yang Cenderung positif. Hal ini dapat disimpulkan bahwa respon siswa kelas VIII B MTs. Muhammadiyah 1 Kota Sorong 
secara keseluruhan memiliki respon cenderung positif terhadap penerapan model pembelajaran kooperatif pada materi relasi dan fungsi.

Hasil belajar siswa pada kelas yang diajar dengan menggunakan model pembelajaran kooperatif pada kelas VIII dideskripsikan berdasarkan analisis data tes awal (pretest) dan tes akhir (posttest). Dan hasil pengolahan data hasil belajar siswa diperoleh rekapitulasi data hasil belajar matematika siswa seperti pada tabel VII dibawah ini:

TABEL VII

HASIL BELAJAR SISWA $(\mathrm{N}=30)$

\begin{tabular}{|c|c|c|c|c|c|}
\hline \multirow{2}{*}{$\begin{array}{l}\text { Rentang } \\
\text { Nilai }\end{array}$} & \multirow[t]{2}{*}{ Kategori } & \multicolumn{2}{|c|}{ Fkekuensi } & \multicolumn{2}{|c|}{ Presentase } \\
\hline & & $\begin{array}{l}\text { Pre } \\
\text { test }\end{array}$ & $\begin{array}{l}\text { Post } \\
\text { test }\end{array}$ & $\begin{array}{l}\text { Pre } \\
\text { test }\end{array}$ & $\begin{array}{l}\text { Post } \\
\text { test }\end{array}$ \\
\hline $86-100$ & $\begin{array}{l}\text { Sangat } \\
\text { Baik }\end{array}$ & 0 & 3 & $0 \%$ & $10 \%$ \\
\hline $71-85$ & Baik & 0 & 15 & $0 \%$ & $50 \%$ \\
\hline $56-70$ & Cukup & 0 & 12 & $0 \%$ & $40 \%$ \\
\hline$<55$ & Kurang & 30 & 0 & $100 \%$ & $0 \%$ \\
\hline Jumlah & & 30 & 30 & $100 \%$ & $100 \%$ \\
\hline
\end{tabular}

Tabel VII menunjukkan bahwa kemampuan awal siswa yang dapat dilihat pada hasil pretest menunjukkan bahwa 100\% peserta didik tergolong dalam kategori kurang, sedangkan pada hasil posttest menunjukkan bahwa hanya $10 \%$ siswa yang berada pada kategori sangat baik, $50 \%$ berada pada kategori baik dan $40 \%$ berada pada kategori cukup.

Uji normalitas data digunakan untuk mengetahui apakah data tersebut berdistribusi normal atau tidak. Uji normalitas data dilakukan dengan program SPSS 24.0 pada soal pretes dan posttest dapat dilihat pada tabel VIII sebagai berikut:

\section{TABEL VIII}

UJI NORMALITAS

One-Sample Kolmogorov-Smirnov Test

\begin{tabular}{lll} 
& & Nilai_Posttest \\
\hline $\mathrm{N}$ & & 30 \\
Normal Parameters & Mean & 74.83 \\
& Std. Deviation & 9.139 \\
Most Extreme & Absolute & .129 \\
Differences & Positive & .129 \\
& Negative & -.085 \\
Test Statistic & & .129 \\
Asymp. Sig. (2-tailed) & & .200 \\
\hline
\end{tabular}

Berdasarkan tabel VIII terlihat bahwa uji normalitas posttest berada pada distribusi normal. Hal ini dilihat berdasarkan taraf signifikansi. Dapat dilihat pada statistik Kolmogorov-Smirnov pada nilai posttest 0,200. Data tersebut normal karena memenuhi kriteria yaitu $0,200>5 \%$ sehingga pengujian hipotesis dapat diteruskan.
TABEL IX

UJI t PAIRED SAMPEL KELAS EKSPERIMEN

\begin{tabular}{cclll}
\hline \multicolumn{3}{l}{ Pretest - Posstest } & Kriteria & Keputusan \\
t hitung df & $\begin{array}{l}\text { Sig. } \\
\text { (2tailed) }\end{array}$ & & \\
\hline- & 29 & 0,000 & $\begin{array}{l}0,000< \\
0,05\end{array}$ & H0 ditolak \\
24,650 & & & 0 \\
\hline
\end{tabular}

Berdasarkan tabel hasil uji $\mathrm{t}$ diatas, diperoleh nilai thitung pada pretest dan posttest sebesar -24,650, nilai thitung negatif karena berada di daerah penolakkan H0 di uji pihak kiri, karena thitung < ttabel maka H0 ditolak. Untuk ttabel diperoleh dengan melihat tabel distribusi t dengan memperhatikan derajat kebebasan atau degree of Freedom/df (n-k) dan taraf signifikansi $\left({ }^{\alpha}\right)$, dimana dalam penelitian ini nilai ttabel untuk $\mathrm{df}=\mathrm{n}-\mathrm{k}=29$ dan ${ }^{\alpha}=0,05$ adalah sebesar 2,045.Dari data diatas tampak bahwa thitung $(-24,650)<$ ttabel $(2,045)$ dengan tingkat signifikansi $0,000<0,05$ yang berarti bahwa variabel kecerdasan emosional dalam Model Pembelajaran Kooperatif berpengaruh signifikansi terhadap hasil belajar siswa kelas VIII MTs. Muhammadiyah 1 Kota Sorong.

Uji regresi sederhana pada penelitian ini dibuat untuk mengetahui apakah Emotional Intelligence (kecerdasan emosional) berpengaruh secara signifikan terhadap hasil belajar. Kriteria pengujian dengan kaidah, H0 diterima jika $\mathrm{t}$ tabel $<\mathrm{t}$ hitung $<\mathrm{t}$ table dan $\mathrm{H} 1$ diterima jika $-\mathrm{t}$ hitung $<-\mathrm{t}$ tabel atau thitung $>\mathrm{t}$ tabel

TABEL $\mathrm{X}$

UJI REGRESI SEDERHANA

\begin{tabular}{lllllr}
\hline \multirow{2}{*}{ Variabel } & \multicolumn{2}{c}{ Coefficient } & & \multirow{2}{*}{ S } \\
\cline { 2 - 3 } & \multicolumn{1}{c}{ B } & Std. Error & & Sig. \\
\hline (Constant) & 36,518 & 8,950 & 4,080 & 0,000 \\
Kecerdasan & 0,522 & 0,121 & & 4,328 & 0,000 \\
emoional & & & & \\
\hline
\end{tabular}

Hasil perhitungan koefisien regresi sederhana diatas memperlihatkan nilai koefisien Constant adalah sebesar 36,518 dan koefisien variabel bebas adalah 0,522 sehingga persamaan regresi pada pengaruh Emotional Intelligenceterhadap hasil belajar siswa adalah $\mathrm{Y}=36,518+$ $0,522 \mathrm{X}$, besarnya pengaruh dari hasil uji regresi pada nilai $\mathrm{b}$ 0,522 , setiap penambahan $1 \%$ kecerdasan emosional maka maka akan mempengaruhi nilai a 36,518 pada hasil belajar karena nilai koefisien regresi bernilai positif, maka dengan demikian dapat dikatakaan bahwa kecerdasan emosional berpengaruh positif terhadap hasil belajar siswa.

Berdasarkan persamaan diatas nilai $b$ adalah 0,522 kemudian nilai thitung > ttabel $(4,328>2,048)$ maka H0 ditolak, jadi ada pengaruh yang signifikan antara kecerdesan emosional terhadap hasil belajar.

Pembahasan 
Hasil belajar merupakan bagian terpenting dalam pembelajaran, pada hakikatnya hasil belajar adalah perubahan tingkah laku sebagai hasil belajar dalam pengertian yang lebih luas mencakup bidang kognitif, afektif, dan psikomotorik. Kecerdasan emosional menjadi salah satu faktor yang penting yang seharusnya dimiliki oleh siswa yang memiliki kebutuhan untuk meraih hasil belajar yang lebih baik disekolah. pada bagian analisis statistik deskriptif untuk lembar observasi aktivitas siswa yang diamati dan diolah menunjukkan rata-rata lembar observasi aktivitas siswa tentang kecerdasan emosional siswa pada saat proses pembelajaran berlangsung pada setiap pertemuan berada pada kategori baik, Untuk Angket respon siswa menunjukkan bahwa rata-rata angket respon siswa adalah 3,1 dengan kategori cenderung positif dan untuk hasil belajar peserta didik, $10 \%$ siswa yang berada pada kategori sangat tinggi, $40 \%$ berada pada kategori tinggi dan $50 \%$ berada pada kategori sedang. Ini sesuai dengan Eva Nauli Thaib (2013: 15) bahwa kecerdasan emosional merupakan salah satu faktor yang membantu siswa untuk meraih prestasi belajar yang lebih baik.

Berdasarkan analisis statistik inferensial dapat dijelaskan bahwa hasil analisis inferensial hipotesis pada Uji t- 2 Sampel Berpasangan (Paired Sampel) menunjukkan hasil yang signifikan antara kecerdasan emosional (emotional intelligence) terhadap hasil belajar siswa. Berdasarkan persamaan regresi pada pengaruh kecerdasan emosional (emotional intelligence) siswa terhadap hasil belajar adalah $\mathrm{Y}=36.518+0,522 \mathrm{X}$ dan berdasarkan perhitungan regresi nilai thitung $>$ ttabel $(4,328>2,048)$, jadi ada pengaruh yang signifikan antara kecerdesan emosional terhadap hasil belajar. Dengan demikian model persamaan regresi memenuhi kriteria, besarnya pengaruh dari hasil uji regresi pada nilai $b$ 0,522, setiap penambahan $1 \%$ kecerdasan emosional maka maka akan mempengaruhi nilai a 36,518 pada hasil belajar maka adanya pengaruh kecerdasan emosional terhadap hasil belajar siswa berdasarkan uji regresi.

\section{SIMPULAN}

Berdasarkan hasil analisis data dan pembahasan dapat dibuat kesimpulan bahwa Pengaruh emotional intelligence siswa terhadap hasil belajar siswa setelah diterapkan model pembelajaran kooperatif dapat dilihat besarnya pengaruh dari hasiluji regresi pada nilai b 0,522 , setiap penambahan $1 \%$ kecerdasan emosional maka maka akan mempengaruhi nilai a 36,518 pada hasil belajar. Dan terdapat peningkatan hasil belajar siswa pada kelas yang diajar dengan adanya emotional intelligence yang diterapkan pada model pembelajaran kooperatif dapat dilihat dari rata-rata pretest 18,88 sebelum perlakuan dan setelah adanya perlakuan nilai posttest mencapai 74,83 .

\section{Referensi}

Anwar, Z., \& Arsyad, R. B. (2019). Profil Kemampuan Siswa SMP dalam Memecahkan Masalah Matematika
Open-Ended Berdasarkan Kemampuan Prasyarat Tinggi. Qalam: Jurnal Ilmu Kependidikan, 7(2), 107-114.

Badan Pusat Statistik Provinsi Papua Barat. 2016. "Provinsi Papua Barat Dalam Angka". Papua Barat : BPS Profinsi Papua Barat.

Firmansyah, I. 2010. "Pengaruh Tingkat Kecerdasan Emosional Terhadap Prestasi Belajar Siswa SMA Triguna Utama Ciputat". Skripsi. Jakarta : Universitas Islam Negeri Syarif Hidayatullah.

Kemdikbud. 2015. "Panduan penilaian Untuk Sekolah Menengah Pertama (SMP)". Jakarta : Ditjen Pendidikan Dasar dan Menengah

Kemdikbud. 2016. "Materi Pelatihan Kurikulum 2013 Mata Pelajaran Matematika". Jakarta : Ditjen Pendidikan Dasar dan Menengah.

Kumala, M. 2015. "Pengaruh Kecerdasan Emosional Pada Kinerja Karyawan Yang Dimediasi Oleh Gaya Manajemen Konflik Kolaborasi Dan Kompromi”. Skripsi. Semarang : Universitas Negeri Semarang.

Permendikbud (2013). Peraturan menteri pendidikan dan Kebudayaan Nomor 66 tahun 2013 Tentang Standar Penilaian Pendidikan

Naqvi, I. H, Iqbal, M, \& Akhtar, S. N. 2016. "The Relationship between Emotional Intelligence and Performance of Secondary School Teachers". Bulletin of Education and Research June 2016, Vol. 38, No. 1 pp. 209-224.

Setyo, A. A. 2016. "Keefektifan Pembelajaran Kooperatif Tipe STAD Dengan Memanfaatkan Teori Belajar Van Hiele Untuk Materi Geometri Di Kelas SD Inpres 109 Perumnas Kota Sorong". Tesis. Kota Sorong : Universitas Negeri Makassar.

Sugiyono. 2012. Metode Penelitian Pendidikan: Pendekatan Kuantitatif, Kualitatif, dan R \& D. Bandung: Alfabeta.

Sugiyono. 2015. Metode Penelitian Pendidikan: Pendekatan Kuantitatif, Kualitatif, dan R\&D. Bandung : Alfabeta.

Thaib, E. N. (2013). Hubungan Antara prestasi belajar dengan kecerdasan emosional. JURNAL ILMIAH DIDAKTIKA: Media Ilmiah Pendidikan dan Pengajaran, 13(2).

Zarkasyi, W. 2015. Penelitian Pendidikan Matematika. Bandung : Refika Aditama. 